\title{
Design Thinking as a strategy to inculcate Problem- based Learning (PBL) in undergraduate education across South Asian Universities
}

\begin{abstract}
The Bologna declaration states that, "successful learning and studying in higher education should involve students in deep learning". However, a survey of faculty across institutes in Nepal and Bhutan highlights that the undergraduate students in engineering and management lack skills needed to be industry-ready. They face difficulty in getting employed after graduation and if placed, then struggle during their employment due to insufficient practical experience, lack of good communication skills and unawareness of larger socio-economic contexts. The Erasmus+ funded project, "Strengthening Problem-based learning in South Asian Universities"(PBL South Asia) is an endeavour to address these pressing concerns in education quality, employability and overall sustainable development of the region and to imbibe deep learning capabilities. Therefore, as an empirical study to clarify and in turn, inculcate PBL in South Asian undergraduate education, the young faculty of the inexperienced institutes from Nepal and Bhutan, alongside the students from the experienced institutes from India and Europe, were mentored by faculty and researchers from the latter to undertake multidisciplinary case studies. The strategy of 'Design Thinking' was employed to methodologically guide the cases and keep it consistently problem-based, i.e., the learning is driven by the problem with no one correct solution. Results showed that the participants reflected improvement in problem-solving skills and increased motivation, apart from enhanced collaboration and improved communication ability. Based on these findings, further development of curricula to imbibe PBL in its existing courses and guidelines to train the trainers for implementation of the same, is currently in progress.
\end{abstract}

Keywords: Design Pedagogy, Design Thinking, Problem-based Learning

\section{Introduction}

The World Economic Forum 2016 [1] recognises critical thinking, complex problem solving, self-learning, collaboration and people management, and communication as top skills for 2020. Problem-based Learning (PBL) methods support these specific skills [2] by positioning the onus of learning on the student through "investigation and resolution of messy, real-world problems" [3]

Globally and in South Asia, Engineering is the preferred undergraduate program of study, followed by Management. Ideally, these programs should enable the graduates to 'design effective solutions to meet social needs' [4] However, the Bologna process identifies 'employability of graduates' and 'shortage of skills in key areas' as major challenges in higher education and outlines objectives to promote employability [5]. Its Declaration states that "successful learning and studying in higher 
education should involve students in deep learning". [5] Unfortunately, literature reports that students are not industry-ready as they lack communication skills and teamwork experience, as well as awareness about social, environmental, economic and legal issues, and programs, being content driven instead of need-driven, do not provide sufficient design experiences to these students [6].

A survey of five South Asian Universities, from Nepal and Bhutan, corroborated the same and revealed that the undergraduate curricula across the region are predominantly instructional and are not adequately hands-on, due several constraints, such as;

- University directed lesson plans with heavy syllabi to cover and restricted time for practical activities,

- Dearth of motivation in students to self-learn and innovate during the stipulated practical hours within a course,

- Poor critical-thinking ability due to a general lack of awareness on sustainable development goals and their local implications in the students,

- Less number of co-instructors to guide in practical, real-world issues that can be addressed in courses,

- Fewer collaborations in these programs/courses, and

- Poor communication skills

Therefore, to make students industry-ready and motivate them towards development of the five essential top skills for the future [1], inculcating PBL approach into existing undergraduate courses is proposed. However, the lack of experience in practicing PBL gave rise to the need of clarifying; (i) what is PBL?, and (ii) how it can be contextually adopted for South Asia, prior to being incorporated as a pedagogical method in undergraduate studies at South Asian Universities.

The aim of this paper is to present the unique strategy of employing Design Thinking to clarify (i) and (ii) and in turn, inculcate Problem-based Learning, through experiential case studies where young faculty and students collaboratively address complex, real-world problems.

\section{Literature}

\subsection{Problem-based Learning (PBL) : A means to develop top skills}

Problem-based learning (PBL) is a learner-centered approach [7] where students learn through "facilitated problem solving that centers on a complex problem that does not have a single correct answer" [8].

While earlier studies stated that students who experienced PBL showed; (i) improvement in problem-solving skills $[9,10]$ and (ii) increased engagement and motivation to learn, as they preferred PBL to the traditional methods of teaching $[11,3]$. Recent empirical findings for engineering discipline reveals that conceptual understanding is higher through PBL than traditional lectures [12] and peer 
discussion enhances it [13]. This, in turn, nurtures critical thinking skills as sharing of opinions, analysing situations through different perspectives and thinking of more possibilities to solve a problem [14] are results of PBL approach. It is also reported that students perform better in both, interpersonal skills as well as practical domain skills [15].

A creative thinking approach has been used for implementing PBL in the classroom and resulted in enhancement of both, creative skills and technical abilities [16]. This approach is a sub-set of Design Thinking and focusses only on 'problemsolving' whereas PBL and Design take a holistic view, beginning with the problem. In spite of several similarities between PBL and Design Thinking, such as; large number of stages, requirement of motivation, organization skills and capability for group work and collaboration [17], PBL is an instructional, curricular approach where the problem is defined [7] and acts as a 'stimulus for learning' [18], whereas in design, the 'finding' of an appropriate problem is as crucial as solving it [19].

\subsection{Design Thinking :}

Design Thinking is a cognitive process [20] of identifying ill-defined or 'wicked' problems and developing solutions through iterative steps or activities, supported by several methods and tools.

There are several Design Thinking models, of which the most popular are; Stanford's school Design Thinking process [20] and IDEO Human-centered Design Model [21] for generic design, and Pahl and Bietz [22], Hubka and Eder [23], Cross [24], Dieter and Schmidt [25], Eppinger and Ulrich [26] for systematic design process stemming from engineering. These models are either descriptive or prescriptive and use varied terminologies to guide the design process.

However, the common approach of all these models maybe summarised into 4 steps as follows:

1. Identify Requirements from abstract needs and observations upon analysis of ill-defined problems (terms: Understand, Observe, Define, Empathise);

2. Ideate solutions, which involves generating several ideas and combining these into solution alternatives (terms: Ideate, Visualise, Synthesize, Co-create);

3. Consolidate solutions into feasible solutions through development and analysis (terms: Build, Prototype, Simulate, Model); and

4. Select concept, i.e., the most promising solution upon evaluation of alternatives through testing (terms : Test, Validate).

\subsection{Inculcating PBL through Design Thinking methods :}

Upon assessment of needs of the partner South Asian Universities, the following shortcomings and drawbacks were found;

a) Lack of clarity in the understanding of PBL approach.

b) Lack of knowledge of PBL process and methods.

c) Lack of experience in practice of PBL courses.

d) Lack of trained faculty to facilitate PBL courses (and its problems) 
Thus, two needs were broadly identified from the above, that ;

i. There is a need to clarify "what is PBL?" and provide understanding, know-how of processes and methods and hands-on experience of the same; and

ii. there is a need to contextually appropriate the PBL experience with respect to both, the domain of study and the socio-cultural that determine the prioritises and problems of a community or region, so that the untrained faculty can adopt it in the future and facilitate the proposed PBL courses in their home Universities.

\section{Descriptive Study}

Therefore, to address these lacking aspects and familiarise the faculty participants from the partnering South-Asian Universities with PBL, a two-week program at IIT Bombay (IITB), Mumbai, was conceptualised with the aim to 'provide a tangible introduction to PBL case work, engaging in cases with external partners/stakeholders and moving through a full PBL inquiry and design process in a simplified, condensed form'. It was envisioned as a platform for teacher training, reflection and debate on the hands-on implementation of PBL cases through field studies.

\subsection{Workshop Participants and Programme :}

The workshop had about 70 registered participants, divided into 7 teams with 7 8 members each. Every team was assigned a mentor and had access to other resources. The participants were as follows;

- Faculty from five Universities across Nepal and Bhutan,

- Advanced students from three European and two Indian Institutes of Eminence.

- PBL project mentors from European and Indian universities,

- Case owners and subject experts, and

- $\quad$ PBL South Asia project managers and coordinators.

The two-weeks comprised of:

- Lectures on PBL - literature survey on definitions, terms and roles in PBL; history of PBL; PBL process and present application in technical domain with focus on design for Sustainability and well-being.

- Interactive sessions on a few variants of design thinking, prototyping etc.

- A dedicated session on Design Thinking, with problem identification, ideation and decision-making (consolidation and selection) methods, as a framework to guide the casework and enable the application of the same during the assignments; and 
- Case studies that involved field work for data collection and validation from local communities and stakeholders, as well as development of their 'problem statement', analysis, conceptualisation and final presentation.

\subsection{Workshop Cases : Problem briefs and Teams}

The cases were as follows:

a. Liveability in Slums (2 teams)

The teams were required to take up challenges surrounding the theme of ' $50 \%$ of the urban population of Mumbai residing in slums, chawls and squatter settlements' and work on possible interventions to improve the conditions surrounding the living in the slums in Mumbai. The study would aim to observe and analyse the liveability of people residing in these units. The study would involve analysis of the neighbourhoods, interaction spaces, built-up area and so on. The teams were expected to define the parameter for living conditions and how their intervention will improve that particular parameter.

b. Affordable Housing (2 teams)

The theme of this case was to understand the affordability in Indian conditions. The teams would define opportunities related to how to make these projects more affordable as well as comfortable for people to live in. Teams visited the organization's sites to understand the execution of projects in Indian conditions. And also looked at use of energy simulations, thermal comfort simulations etc. to arrive at possible interventions.

c. Construction Demolition Waste (1 team)

The challenge in this theme was for the team to identify the creative uses for the use of construction demolition waste in the country. The teams visited sites of construction demolition as well as some recycling plants and laboratories to acquaint themselves with the dynamics of CDW, and worked on how to creatively utilize the CDW in the society. The students were given access to the materials laboratory of IIT Bombay to cast and test some materials/prototypes made out of CDW.

d. Accessible Healthcare (1 team)

Parents of hearing-impaired children need to consistently deliver goal-oriented speech therapy at home, otherwise the child's progress in learning to understand language and speak will be hampered. The team was expected to address the accessibility of such a health care need and propose how to motivate parents and children to conduct therapy at home.

e. Net zero energy development - rehabilitating sustainably: Redevelopment of Artist Village in Belapur (1 team) 
Based on the details, the team needed to develop a prototype model for incremental housing in the area, focusing on energy efficiency and sustainability without compromising on living standards and affordability. The prime focus was more on the possibility of renovation and extension of existing structure rather than planning the area from ground zero, with the intention to look at how to develop brown field projects sustainably in contrast to greenfield projects.

f. Net zero energy development - rehabilitating sustainably : Modular Housing scheme for Bhiwandi locality (1 team)

Bhiwandi, an area located in the Eastern suburbs of Mumbai, is predominantly a textile hub which has the largest number of Power Looms in the country. A major chunk of the population is employed in this sector, but the residential area is lesser developed to the Industrial Area. In order to end this disparity, a number of Housing Schemes have been coming up in the area recently. The aim was to create a prototype for modular housing which would fall under the affordable category. The focus would be on multi-utility areas including modularization, affordability, energy usage etc. based on the user group.

\section{Case study : An example}

As an exemplar, the PBL process of the above case study ( $f$ ) on 'Modular Housing for Bhiwandi locality', using Design Thinking as a framework, is presented.

\subsection{Problem Identification}

4.1.1. "Problem" extracted from given brief : How to provide affordable and modular housing in Bhiwandi?

4.1.2. The team observed and demarked the system boundary as 'Bhiwandi locality' and enlisted a number of probable problems and concerns to be considered for both, the locality and modular housing in general, enlisted in Table 1 (Col. I).

4.1.3 Based on the above, a Preliminary List of Requirements was generated. As in Table 1 (Col. II).

4.1.4 Field visit was conducted to clarify the requirements, as well as, secondary research on climate and temperature data, wind flow pattern and population.

4.1.5 Stakeholder Interviews were conducted with questions categorized under the three pillars of sustainability, namely;

- $\quad$ Social aspects (What works - what do they like? What doesn't - what should be improved? Does it feel safe? Comfortable? What would they want if they moved to a new home?),

- Environmental aspect (What kind of annual environmental changes take place? How do they adapt to them? How does water management work? What about waste management?)

- Economic aspects (Is it affordable? Would they prefer to buy or rent?) 
4.1.6 Insights were drawn from the responses of the interviews and the problem statement was redefined to "How to provide affordable, safe and spacious housing for Bhiwandi's low-income labour/workers through modular solutions?"

Table 1. List of Problems and Preliminary Requirements

\begin{tabular}{|c|c|c|}
\hline I. & PROBABLE PROBLEMS & $\begin{array}{l}\text { PRELIMINARY LIST OF } \\
\text { REQUIREMENTS }\end{array}$ \\
\hline & $\begin{array}{l}\text { locality; } \\
\circ \text { Accommodating low in- } \\
\text { come group } \\
\circ \quad \text { Risk of flooding in mon- } \\
\text { soon } \\
\circ \text { Adaptation capacity } \\
\circ \text { Risk of high temperature } \\
\text { and humidity } \\
\circ \quad \text { Scarcity of pure drinking } \\
\text { water } \\
\text { Improper waste manage- } \\
\text { ment system } \\
\circ \text { Ground/land strata } \\
\circ \text { Availability of space for } \\
\text { construction } \\
\circ \text { Risk of earthquakes } \\
\text { modular housing ; } \\
\circ \text { Environmental sustainabil- } \\
\text { ity } \\
\circ \text { Socio-cultural adaptation } \\
\circ \\
\text { Economic feasibility }\end{array}$ & $\begin{array}{l}\text { 1. Need low cost rental/own housing } \\
\text { 2. Modular system should withstand } \\
\text { flooding } \\
\text { 3. Modular system should withstand } \\
\text { high temperature and humidity } \\
\text { 4. Need provision for pure drinking } \\
\text { water } \\
\text { 5. It should inhibit waste manage- } \\
\text { ment system } \\
\text { 6. It should facilitate construction in } \\
\text { different ground strata } \\
\text { 7. It should withstand mild to severe } \\
\text { earthquakes } \\
\text { 8. Modules should be scalable } \\
\text { 9. Modules should be lightweight to } \\
\text { facilitate transportation } \\
\text { 10. Should facilitate expansion in fu- } \\
\text { ture } \\
\text { 11. Materials and construction pro- } \\
\text { cess should be sustainable } \\
\text { 12. Modular system should encourage } \\
\text { socio-cultural interaction }\end{array}$ \\
\hline
\end{tabular}

4.1.7 Prioritisation of Requirements using Checklist [22]

Table 2. Prioritized List of Requirements

\begin{tabular}{|l|c|c|}
\hline \multicolumn{1}{|c|}{ REQUIREMENTS } & $\begin{array}{l}\text { DEMAND (D) / } \\
\text { WISH (W) }\end{array}$ & PRIORITY \\
\hline Need low cost rental/own housing & $\mathrm{D}$ & 1 \\
\hline Modules should be scalable and flexible & $\mathrm{D}$ & 2 \\
\hline Should facilitate expansion in future & $\mathrm{W}$ & 3 \\
\hline
\end{tabular}




\begin{tabular}{|l|c|c|}
\hline $\begin{array}{l}\text { Materials and construction process should be sus- } \\
\text { tainable }\end{array}$ & W & 4 \\
\hline Need provision for pure drinking water & D & 5 \\
\hline It should inhibit waste management system & D & 6 \\
\hline
\end{tabular}

\subsection{Ideation}

Several ideas were explored for the prioritized requirements (Fig. 01)

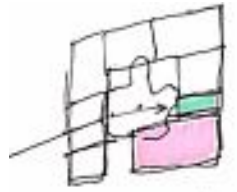

Q1 shored unit

C) is the 2ait

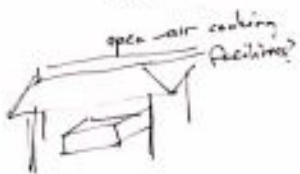

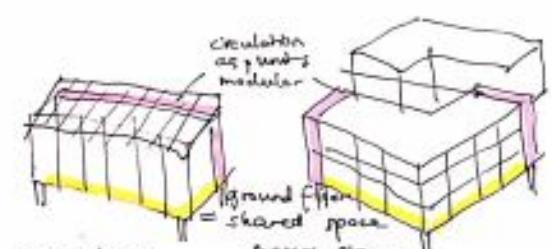

ancel ere.

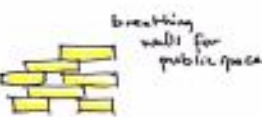

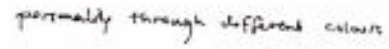
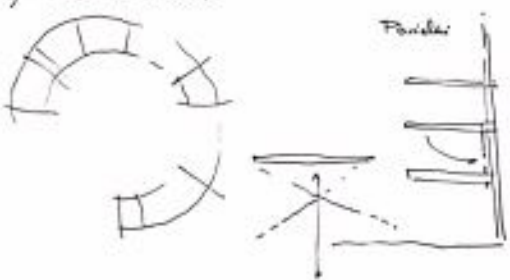

Fig. 1. Ideation : Solution exploration a
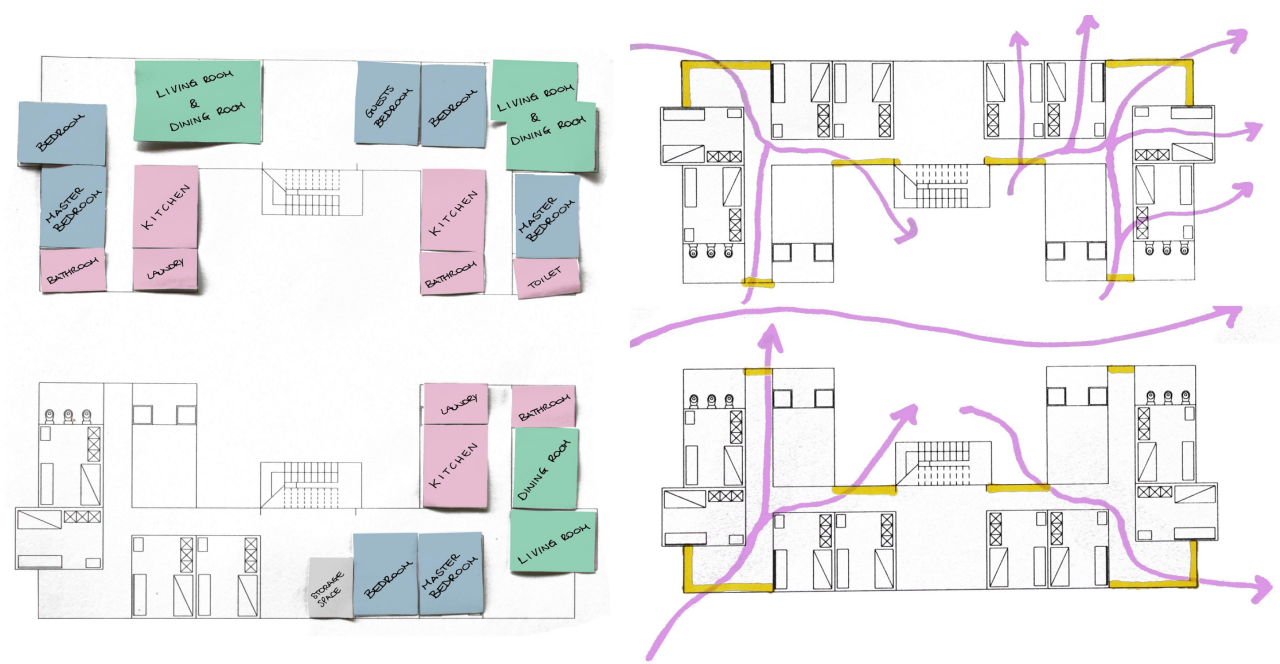

Fig. 2. Selected Concept 1 


\subsection{Solution Consolidation}

Of the ideas and piecemeal solutions generated, some were merged to develop alternatives.

\subsection{Concept Selection}

The concept :'Shared spaces and facilities for different scales' (Fig. 02), was selected as the most promising solution, based on its modular flexibility for different configuration possibilities and breathable walls that take advantage of prevailing wind flows. The concept also entailed a smart energy and waste management systems, with facilities for recycling, Earning opportunities from energy production through small-scale bio gas production and solar PV system integrated to the grid, and Energy saving through Smart switch-off systems, Solar water heating and efficient lights and maximising daylight usage. The team also proposed a 'policy' solution for Renting.

\section{Results and Findings}

A survey was conducted across the participants to assess the overall experience of the workshop as well as seek feedback on methods applied.

It sought detailed response on the various methods - team building methods, field work methods, problem definition and analysis methods, etc. - applied during case work. Experience of mentoring and collaboration in multi-cultural teams was also sought. Participants were asked to self-evaluate their progress in the following areas and skills : development of understanding of sustainability for PBL and apply design thinking, aimed at improving 'Critical thinking, Self-learning and Complex problem-solving'; skills of Team working, Leadership, Project management and increased Motivations and interest, aimed at building 'Collaboration and people management; and improvement in English as well as technical language under 'Communication skills'.

The results and findings were as follows;

- Most participants found the Lecture sessions to be 'fulfilling their expectations', as in Fig.3(a) whereas the relevance and value of the methods sessions were not adequately understood and drew contrasting responses.

- $\quad$ A majority, i.e., $56.4 \%$ of the participants responded positively about their experience of PBL through the PBL test cases, as in Fig. 3(b). However, $41 \%$ stated that the experience only "partially fulfilled their expectations.

- Predominantly, positive feedback was received ranging from 'some progress' to 'significant progress', as in Fig.3(c), upon being asked to self-evaluate on certain areas and skills through the workshop experience. 


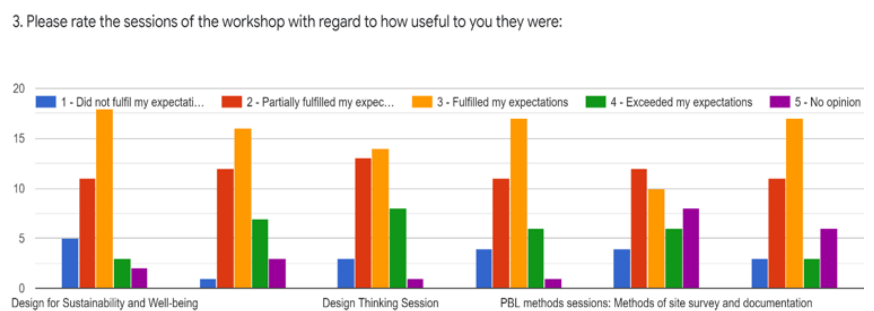

Fig. 3. Survey Results a

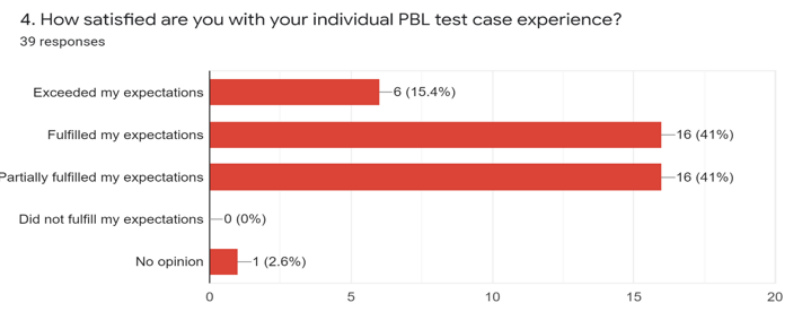

Fig. 3. Survey Results b

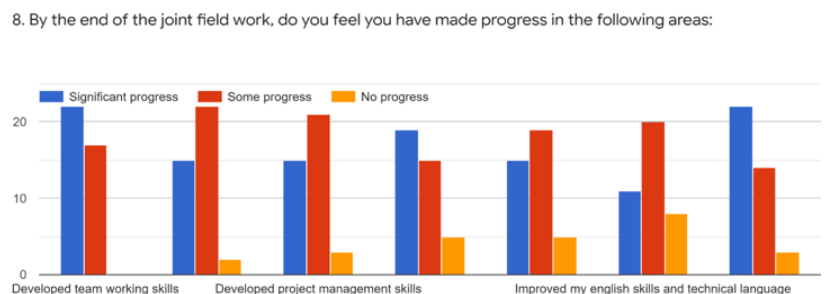

Fig. 3. Survey Results c

\section{Summary, Conclusions and Discussion}

To foster deep learning, and in turn, develop the top skills essential for being industry-ready, a Problem-based Learning (PBL) approach is proposed as a pedagogical methodology to be introduced in South Asian undergraduate programs. However, the dearth of know-how and experience of PBL in the partner universities prompted the novel proposal of using Design Thinking to inculcate PBL into the educators with the hope that they will disseminate the same at their home institutes. In design, unlike in PBL, the problem is not given but identified and so has potential of reflecting the contextual nuances of the domain of study and socio-cultural fabric of South Asia. Thus, a two-week program was hosted at IITB to clarify what is PBL and contextually appropriate it for South Asia, through lectures, hands-on sessions, 
and case studies addressing challenges unique to the region, so that the participants without prior knowledge or training receive a first-hand experience of PBL.

It was noted that the participants successfully completed the PBL case by following the design thinking methods, were overall satisfied with the case experience and reported that they had made some to significant progress with respect to skills.

In conclusion, the two-week program showed promise in inculcating PBL through design thinking in undergraduate level and became a pilot for the further development of PBL courses. Currently, re-designed course with PBL approach is being implemented across the five partner institutes in Nepal and Bhutan and a MOOC is being collaboratively produced by all partners.

\section{Acknowledgments and Disclaimer}

This publication is a result of the 'Strengthening Problem-based Learning in South Asian Universities' (PBL South Asia) project, co-funded by the Erasmus+ programme of the European Union*. This study would not have been possible without the participation of over seventy members from across five countries and ten partner universities, namely, Aalto University, Finland; Indian Institute of Science (IISc) and Indian Institute of Technology Bombay (IITB), India; Kaunas University of Technology (KTU), Lithuania; TU Delft, The Netherlands; JNEC, Royal University of Bhutan, Bhutan; and Kathmandu University, Asian Institute of Technology and Management (AITM), Sagarmatha Engineering College and Nepal Engineering College, Nepal.

* The European Commission's support for the production of this publication does not constitute an endorsement of the contents, which reflect the views only of the authors, and the Commission cannot be held responsible for any use which may be made of the information contained therein.

\section{References}

1. WEF, W. (2016). The World Economic Forum.

2. Duch, Barbara J., Susan E. Groh, and Deborah E. Allen (2001) The power of problembased learning: a practical" how to" for teaching undergraduate courses in any discipline. Stylus Publishing, LLC..

3. Torp, Linda, and Sara Sage (2002) Problems as Possibilities: Problem-Based Learning for K-16 Education

4. McNeill, B.W., Evans, D.L., Bowers, D.H., Bellamy, L. and Beakley, G.C. (1990) Beginning design education with freshmen. Engineering Education, 80(5), pp.548553.

5. Declaration, Bologna (2009) The European Higher Education Area, Joint Declaration of the European Ministers of Education, convened in Bologna, 19 June 1999. Retrieved November 8 (1999).

6. Mills, Julie E., and David F. Treagust (2003) Engineering education-Is problembased or project-based learning the answer." Australasian journal of engineering education 3, no. 2, pp. 2-16.

7. Savery, John R (2015) Overview of problem-based learning: Definitions and distinctions. Essential readings in problem-based learning: Exploring and extending the legacy of Howard S. Barrows 9 pp.5-15. 
8. Hmelo-Silver, Cindy E (2004)Problem-based learning: What and how do students learn? Educational psychology review 16, no. 3, pp. 235-266.

9. Albanese, Mark A., and Susan Mitchell (1993) Problem-based learning: A review of literature on its outcomes and implementation issues. Academic MedicinePhiladelphia- 68, pp. 52-52.

10. Vernon, David T., and Robert L. Blake (1993) Does problem-based learning work? A meta-analysis of evaluative research. Academic medicine .

11. Denton, Betty G., Cara C. Adams, Phillip J. Blatt, and Christopher D. Lorish. "Does the introduction of problem-based learning change graduate performance outcomes in a professional curriculum." Journal on Excellence in College Teaching 11, no. 2-3 (2000): 147-162.

12. Yadav, Aman, Dipendra Subedi, Mary A. Lundeberg, and Charles F. Bunting (2011) Problem-based learning: Influence on students' learning in an electrical engineering course. Journal of Engineering Education 100, no. 2, pp. 253-280.

13. Spronken-Smith, Rachel, and Tony Harland (2009) Learning to teach with problembased learning. Active Learning in Higher Education 10, no. 2, pp. 138-153.

14. Rideout, Elizabeth, and Barbara Carpio (2001) Learning Model of Nursing Education." Transforming nursing education through problem-based learning. pp. 21.

15. Schmidt, Henk G., Henk T. Van der Molen, Wilco WR Te Winkel, and Wynand HFW Wijnen (2009) Constructivist, problem-based learning does work: A meta-analysis of curricular comparisons involving a single medical school." Educational psychologist 44, no. 4, pp. 227-249.

16. Awang, H. and Ramly, I. (2008) Creative thinking skill approach through problembased learning: Pedagogy and practice in the engineering classroom. International journal of human and social sciences, 3(1), pp.18-23

17. Williams, A., Williams, P.J., Ostwald, M. and Kingsland, A., 1994. Problem based learning: An approach to teaching technology. Research and development in problembased learning, 2, pp.355-367.

18. Barrows, Howard S (1996) What Your Tutor May Never Tell You: A Medical Student's Guide to Problem-based Learning (PBL). Southern Illinois University School of Medicine, 1996.

19. Cross, Nigel (2001) Design cognition: Results from protocol and other empirical studies of design activity. In Design knowing and learning: Cognition in design education (pp. 79-103). Elsevier Science.

20. Plattner, H., Meinel, C., \& Weinberg, U. (2009). Design-thinking. Landsberg am Lech: Mi-Fachverlag.

21. Brown, T., \& Wyatt, J. (2010). Design thinking for social innovation. Development Outreach, 12(1), 29-43.

22. Beitz, W., Pahl, G., \& Grote, K. (1996). Engineering design: a systematic approach. MRS BULLETIN, 71.

23. Hubka, V., \& Eder, W. E. (2012). Theory of technical systems: a total concept theory for engineering design. Springer Science \& Business Media.

24. Cross, N. (2001). Designerly ways of knowing: Design discipline versus design science. Design issues, 17(3), 49-55.

25. Dieter, G. E., \& Schmidt, L. C. (2009). Engineering design. Boston: McGraw-Hill Higher Education.

26. Eppinger, Steven, and Karl Ulrich. Product design and development. McGraw-Hill Higher Education, 2015. 